\title{
IMPLEMENTASI PROGRAM AKSELERASI (STUDI KASUS) DI SD MUHAMMADIYAH SAPEN YOGYAKARTA
}

\author{
Basuki \\ SD Bantul Timur Yogyakarta \\ basukibtm@yahoo.co.id
}

\begin{abstract}
Abstrak
Penelitian ini bertujuan untuk mendeskripsikan: (1) implementasi program akselerasi di SD Muhammadiyah Sapen Yogyakarta, dan (2) kendala yang dihadapi dalam pelaksanaan program akselerasi di SD Muhammadiyah Sapen Yogyakarta. Jenis penelitian ini adalah kualitatif. Teknik pengumpulan data yang digunakan yaitu wawancara, observasi, dan dokumentasi. Hasil dari penelitian ini adalah: (1) implementasi program akselerasi meliputi: (a) rekrutmen siswa akselerasi melalui dua tahapan yaitu informasi dan seleksi; (b) upaya peningkatan kemampuan guru melalui diklat dan pendampingan dari UKP UGM; (c) pemanfaatan sarana dan prasarana didukung oleh sumberdaya manusia sesuai ahlinya supaya efektif dan efisien; dan (d) upaya kepala sekolah memotivasi guru akselerasi dilakukan setiap ada pertemuan, secara finansial guru akselerasi mendapat intensif, dan pemberian motivasi dari UKP UGM. (2) kendala yang ada dalam implementasi program yaitu adanya sebagian orang tua siswa tidak maksimal dalam pendampingan anaknya dan kebosanan anak dalam belajar karena beban tugas dan ulangan.
\end{abstract}

Kata kunci: implementasi, program, dan akselerasi.

\section{THE IMPLEMENTATION ACCELERATED PROGRAM (A CASE STUDY) AT SD MUHAMMADIYAH SAPEN YOGYAKARTA}

\author{
Basuki \\ SD Bantul Timur Yogyakarta \\ basukibtm@yahoo.co.id
}

\begin{abstract}
This research aims to find out: (1) the implementation acceleration of the program in $S D$ Muhammadiyah Sapen Yogyakarta, and (2) the constraints faced in the implementation of the program acceleration in SD Muhammadiyah Sapen Yogyakarta. This type of research is qualitative to describe the implementation of the accelerated program in SD Muhammadiyah Sapen Yogyakarta. The data collection techniques were interviews, observation, and documentation. The results of this study are as follows: (1) implementation of the acceleration program include: (a) recruitment of students through two stages, namely information and selection; (b) efforts to increase the ability of teachers through training and mentoring of UKP UGM; (c) the use of facilities and infrastructure supported by appropriate human resource experts to be effective and efficient; and $(d)$ the principal effort to motivate teachers acceleration is done whenever there is a meeting, financially teachers received intensive acceleration, and the motivation of UKP UGM (2) the constraints that exist in the implementation of the program that is the majority of parents are not maximal in mentoring children and children feel bored because of the st and tests.
\end{abstract}

Keywords: implementation, program, and acceleration. 


\section{Pendahuluan}

Kebutuhan pelayanan bagi siswa cerdas istimewa merupakan suatu keharusan di negara ini. Pelayanan ini tentu memerlukan kerja sama yang serius oleh pemerintah, psikolog, pengelola pendidikan, masyarakat, dan orang tua siswa.

PP Nomor 19 Tahun 2005 tentang Standar Nasional Pendidikan mengamanatkan bahwa setiap pendidik harus memiliki kualifikasi kompetensi sebagai agen pembelajaran, sehat jasmani dan rohani serta memiliki kemampuan untuk mewujudkan tujuan pendidikan nasional. Kualitas akademik adalah tingkatan pendidikan minimal yang harus dimiliki oleh seorang guru. Kompetensi guru sebagai perencana, pelaksana dan penilaian pembelajaran meliputi (a) kompetensi pedagogik, (b) kompetensi kepribadian, (c) kompetensi sosial, dan d) kompetensi profesional

Yusuf (2007, p.170) menyebutkan "Model pendidikan anak berbakat dapat dilaksanakan dengan berbagai model, seperti: akselerasi, pengayaan, dan pengelompokkan berdasarkan kemampuan." Akselerasi adalah suatu bentuk pengajaran kepada individu atau kelompok dengan cara memberi kesempatan kepada anak yang bersangkutan untuk naik ke tingkatan kelas berikutnya lebih cepat (double promotion) satu atau dua kali sekaligus Hamalik (Hidayat, 2010, p.12). Program akselerasi merupakan program layanan pendidikan yang diberikan kepada anak yang mempunyai cerdas istimewa dan berbakat istimewa (CI-BI)

Guru mempunyai peran yang strategis dalam membimbing kelas akselerasi. Hal ini untuk mengantarkan siswa cerdas istimewa/giffted berkembang sesuai dengan bakat yang dimilikinya, adapun peranan guru menurut Tirtonegoro (1984, pp.105-106) sebagai berikut: (1) guru untuk kelompok anak cerdas istimewa/giffted harus merupakan guru yang fleksibel, artinya selalu dapat memberi kesempatan kepada anak-anak untuk dapat mengembangkan bakatnya, (2) bersikap toleran, dapat memberikan inspirasi, bimbingan dan kesempatan bagi mereka untuk mencoba- kan kemampuan mereka mengadakan eksplorasi dan menghasilkan sesuatu, (3) bersikap mengabdi (dedikasi), siap membimbing anak kearah kehidupan dan belajar efektif adalah merupakan tanggung jawab guru, (4) dapat memberikan modal pada minat dan bakat anak serta dapat membantunya untuk memperluas minatnya untuk memperhatikan bidang-bidang yang masih belum dikenalnya dan (5) guru harus dapat membimbing murid yang cakap ke arah sikap kemauan menerima (асcеptance), suatu pandangan terhadap sesuatu (aspirasi) yang beralasan dan suatu tujuan yang realistis.

Perangkat perundangan untuk pelayanan pada siswa cerdas istimewa sudah cukup jelas. Penerapan dan pelayanan sendiri belum maksimal meskipun sudah ada pelayanan. Berbagai aspek dapat menentukan keberhasilan pelayanan anak cerdas istimewa.

Aspek ketenagaan, guru yang mengajar di program akselerasi tidak disiapkan secara khusus. Lebih jauh bahkan tidak ada kriteria tertulis, prasyarat guru ditekankan pada kinerja saja. Artinya mereka bergantiganti sebagai pengajar di program akselerasi. Tenaga pendidik menurun semangat/etos kerja pengajar program akselerasi yang menuntut tambahan insentif, karena harus mengajar di program akselerasi.

Aspek pembelajaran, proses yang terjadi di dalam dan di luar kelas, masih menekankan pada pencapaian daya serap materi. Hal ini mengakibatkan siswa akseralerasi menerima beban lebih berat karena penyelesaian studi yang lebih cepat. Akibatnya model pembelajaran yang digunakan juga tidak berbeda dengan siswa reguler. Sementara itu pemanfaatan ICT dalam proses pembelajaran juga relatif terbatas, karena kemampuan guru dalam bidang itu juga terbatas.

Di sisi lain, ditemukan adanya program remedial bagi siswa akselerasi yang tidak mencapai KKM yang ditentukan sekolah. Dari aspek kesiswaan, belum semua siswa dengan kualifikasi siswa cerdas istimewa dapat mengelola waktunya untuk mengikuti kurikulum akselerasi. Akibat- 
nya siswa tersebut jadi siswa biasa. Hal ini dapat mengakibatkan potensi siswa menjadi sia-sia. Sedangkan potensi lain siswa kelas akselerasi tidak dapat berkembang secara optimal karena beban belajar akibat percepatan. Guru sebagai ujung tomak dari implementasi kurikulum ini segera bertindak mencari penyebabnya pada diri anak tersebut.

Sekolah yang menyelenggarakan pendidikan khusus untuk siswa yang selama ini dilayani dalam bentuk program akselerasi perlu dilakukan pembenahan. Pembenahan yang dilakukan mencakup seluruh aspek penyelenggaraan pendidikan itu. Salah satu upaya pembenahan adalah dengan melibatkan semua pihak terkait untuk melakukan pembenahan tersebut. Hal ini menjadi penting, karena selama ini sekolah-sekolah penyelenggara akselerasi berjalan sendirian dan sebatas menjadi operator kebijakan.

Pembenahan yang dilakukan dengan penerapan kurikulum akselerasi di sekolah penyelenggara kelas akselerasi. Penerapan yang dilakukan dapat dilihat dari berbagiai aspek, yakni: rekrutmen siswanya, peningkatan kemampuan guru, pemberian motivasi kepala sekolah pada guru, dan supervissi kepala sekolah. Pembenahn dari berbagai aspek ini saling berkaitan satu dengan yang lainnya. Rekrutmen yang sesuai dengan aturan memberikan kemudahan untuk penerapan kurikulum akselerasi sehingga sesuai dengan kebutuhan siswa cerdas istimewa.

Kebutuhan pelayanan bagi siswa cerdas istimewa merupakan suatu keharusan di negara ini. Siswa cerdas istimewa merupakan aset negara dalam bentuk sumber potensi yang luar biasa. Apabila pelayanannya tidak sesuai dengan kebutuhaannya maka akan menjadi siswa yang biasa. Pelayanan ini tentu memerlukan kerja sama yang serius oleh pemerintah, psikologi, pengelola pendidikan, masyarakat, dan orang tua siswa .

Psikolog mempunyai peran yang vital untuk rekrutmen siswa cerdas istimewa, diantara rekrutmen didasarkan pada tingkat inteligesi siswa. Batas minimal in- teligensi untuk kelas akselerasi sudah ditentukan oleh pemerintah. Disamping rekrutmen, psikolog mempunyai tugas lain dalam kelas akselerasi ini yaitu pendampingan psikologi siswa.

Kepala sekolah menduduki posisi yang strategis di dalam pencapaian kurikulum kelas akselerasi. Kurikulum yang sudah melalui perencanaan, pengembangan, implementasi dan evaluasi. Evaluasi dilkukan dari perencanaan, implementasi dan evaluasi. Evaluasi itu sendiri juga perlu dievaluasi sudah tepat belum pelaksanaan evaluasi. Diantara evaluasi yang penting adalah melalui supervisi kepala sekolah terhadap pelaksanaan pembelajaran di kelas akselerasi. Evaluasi yang dilakukan untuk menyesuaikan kurikulum dengan kodrat kemampuan peserta didik (tingkat kecerdasan siswa)

Tingkatan kecerdasan siswa dikategorikan tiga kelompok yaitu di bawah ratarata, rata-rata dan diatas rata. Dari tiap kelompok ini mempunyai ukuran pelayanan sendiri-sendiri. Pelayanan kurikulum dan pembelajaran untuk dibawah rata-rata tidak dapat diterapkan untuk pelayanan rata rata dan di atas rata-rata. Begitu juga untuk pelayanan di atas rata- rata tidak dapat diterapkan untuk pembelajaran kelas rata-rata dan dibawah rata rata.

Perekrutan siswa akselerasi di SD Muhammadiyah Sapen didasarkan pada seleksi dari beberapa siswa di SD Sapen yang ada di bawah naungan SD Muhammadiyah Sapen. Rekrutmen dapat menjadi masalah karena kurang keterbukaan dari panitia. Panitia perlu keterbukaan dalam melakukan seleksi dan hasilnya harus dapat dipertanggungjawabkan pada semua yang berkepentingan.

Begitu masuk pada 1 bulan awal, siswa akselerasi baru memulai adaptasi dengan kelas barunya. Peralihan dari kelas reguler ke kelas akselerasi, siswa masih kelihatan kekurangan kesiapan memasuki banyak tugas dan pembelajaran. Pembelajaran di kelas akselerasi membutuhkan dukungan orang tua, psikolog dan komite untuk tercapainya implementasi program akselerasi. 
Anak cerdas istimewa merupakan aset negara yang perlu mendapatkan pelayanan khusus. Pelayanan terhadap anak dapat dilayani dengan program akselerasi. Pelayanan ini bagian dari memberikan keadilan pada anak akselerasi karena belum semua siswa yang mempunyai kecerdasan istimewa ini mendapatkan pelayanan. Pelayanan yang diberikan untuk anak cerdas istimewa memerlukan kontrol dari kepala sekolah.

Siswa cerdas istimewa adalah siswa yang diidentifikasikasi oleh tenaga profesional dan mempunyai kemampuan pencapaian kinerja tinggi. Kinerja tinggi ditunjukan dengan pencapaian dan mempunyai potensi kemampuan dalam salah satu area atau kombinasi beberapa area bidang studi. Adapun area kemampuan yang ditunjukan oleh siswa cerdas istimewa adalah (1) kemampuan kecerdasan umum, (2) bakat akademik khusus, (3) berfikir kreatif dan produktif, (4) kemampuan kepemimpian, (5) kemampuan psikomotorik dan 5) seni peran dan visual (Supriyanto, 2012, p.23)

Kepala sekolah sebagai manajer mempunyai peran supervisi. Peran supervisi dibutuhkan dalam pelaksaanaan program akselerasi. Supervisi bertujuan untuk meningkatkan pelayanan yang maksimal pada siswa cerdas istiewa. Hasil supervisi digunakan untuk umpan balik guru dalam peningkatan pelaksanaan pembelajaran akselerasi. Sudjana (2004, p.12) mengatakan "Manjemen adalah kemampuan dan keterampilan khusus untuk melakukan suatu kegiatan, baik bersama orang lain dalam mencapai tujuan organisasi." Organisasi membutuhkan seseorang yang mempunyai kemampuan dan keterampilan. Kemampuan mempunyai arti bahwa seorang pengelola harus mempunyai ilmunya untuk menggerakkan organisasi. Keterampilan seorang pengelola harus terampil merencanakan, melaksanakan, dan pengawasan terhadap kegiatan. Pendapat ini dapat digunakan dalam penelitian karena dalam pelaksanaan program akselerasi dibutuhkan kemampuan kepala sekolah dalam peningkatan kemampuan guru dan kemampuan kepala sekolah melakukan pengawasan melalui kegiatan supervisi.

Sesuai dengan kodratnya, manusia mempunyai kebutuhan yang mendasar dan kebutuhan berikutnya. Tercapainaya kebutuhan tersebut tidak lepas dari usaha kepala sekolah yaitu melalui upaya motivasi kepala sekolah pada guru akselerasi. Kepala sekolah dalam memberikan motivasi harus memamhami guru akselerasi dan tahapan kebutuhan manusia. Upaya kepala sekolah dalam memotivasi guru akselerasi di SD Muhammadiyah Sapen belum maksimal. Jika kebutuhan dari guru akselerasi belum terpenuhi guru akan kurang maksimal melaksanakan tugasnya.

Berdasarkan uraian tersebut, maka penelitian in bertujuan untuk mendeskripsikan: (1) implementasi program akselerasi di SD Muhammadiyah Sapen Yogyakarta, dan (2) kendala yang dihadapi dalam pelaksanaan program akselerasi di SD Muhammadiyah Sapen Yogyakarta.

\section{Metode Penelitian}

Penelitian ini menggunakan pendekatan kualitatif. Penelitian ini memilih metode kualitatif dengan maksud untuk mengungkapkan makna yang terkandung dalam data yang telah dikumpulkan baik dari data observasi, data wawancara dan data dokumentasi. Hal ini sesuai dengan pendapat Sugiyono (2012, p.19) yang menyebutkan metode kualitatif adalah metode penelitian yang berlandaskan pada filsafat postpositivisme, digunakan untuk meneliti kondisi objek yang alamiah, dimana peneliti adalah sebagai instrumen kunci, teknik pengumpulan data dilakukan secara trianggulasi (gabungan), analisis data bersifat induktif/kualitatif, dan hasil penelitian kualitatif lebih menekankan makna dari pada generalisasi.

Penelitian ini dilaksanakan di SD Muhammadiyah Sapen Yogyakarta. SD ini adalah sekolah dasar yang memiliki program akselerasi di D.I Yogyakarta. Waktu penelitian adalah 17 Januari 2014 sampai dengan 17 Maret 2014. Subjek dalam penelitian ini adalah kepala sekolah yang men- 
jabat di SD tersebut lebih dari 3 tahun, Wali kelas akselerasi yang lebih 3 tahun mengampu kelas akselerasi, Seksi layanan khusus Akselerasi, kabag litbang, seksi PLB Dinas Dikpora DIY dan 8 wali siswa akselerasi di SD Muhammadiyah Sapen Yogyakarta

Instrumen penngumpulan data yang digunakan dalam penelitian ini adalah pedoman wawancara, observasi dan dokumentasi. Penelitian ini menggunakan teknik triangulasi untuk menjaga kredibilitas data yang meliputi triangulasi sumber, teknik, waktu. Analisis data dalam penelitian kualitatif dilakukan pada saat pengumpulan data berlangsung dan setelah pengumpul-an data pada periode tertentu. (Creswell, 2010, p. 274)

Pada saat wawancara, peneliti sudah melakukan analisis terhadap jawaban yang diwawancarai. Aktivitas dalam analisis data yaitu reduksi data, penyajian data dan penarikan kesimpulan dari data yang didapatkan. Mills dan Huberman (Sugiyono, p.246), mengemukakan bahwa aktivitas dalam analisis data kualitatif dilakukan secara interaktif dan berlangsung secara terus menerus sampai tuntas, sehingga datanya sudah jenuh. Aktivitas dalam analisis data, yaitu data reduction, data display, dan conclusion drawing/verification.

\section{Hasil Penelitian dan Pembahasan}

Penelitian dilakukan di SD Muhammadiyah Sapen Yogyakarta yang melaksanakan program pelayanan akselerasi dan hanya satu-satunya saat ini di Daerah Istimewa Yogyakarta.

Profil sekolah yang dimaksud mencakup beberapa hal yakni: sejarah kelas akselerasi, kondisi guru dan tenaga kependidikan, kondisi siswa, prestasi siswa akselerasi, dan visi misi sekolah.

Sejak tahun 1994 SD Muhammadiyah Sapen telah melaksanakan program akselerasi yang diberi nama program PATAS (cepat tuntas). Proses penyaringan PATAS saat itu sangat ketat, dengan kriteria nilai akademik rata-rata 5 mapel minimal 9,0, Kelas 1-3 selalu juara 1, Test psikologis dan kesehatan. Saat itu program PATAS berhasil meluluskan: PATAS lulusan pertam (1 siswa) dan PATAS lulusan kedua (1 siswa).

Ketika pemerintah mencanangkan program akselerasi pada tahun 2002, SD Muhammadiyah Sapen diberi amanat untuk mengelola kelas akselerasi yang diperkuat dengan SK Akselerasi dari Dirjen Dikdasmen Depdiknas No. 509/C/Kep.MN/ 2002. Dengan dasar tersebut SD Muhammadiyah Sapen dan sekolah binaannya (Sagan, Kauman, Patehan, Karangwaru, Nitikan, Gowongan, dan Papringan) melaksanakan Program PATAS secara serentak dengan menggunakan PATAS Pola 2 ( Tipe I/II PATAS). Data siswa PATAS untuk SDM. Sapen adalah sebanyak 40 siswa

Tahun Ajaran 2003/2004 SD Muhammadiyah Sapen melaksanakan program akselerasi/PATAS dengan menggunakan Pola I (Tipe I-VI PATAS) yakni pembelajaran selama 6 tahun diselesaikan dalam waktu 5 tahun untuk seluruh siswa kelas I. Pelaksanaan PATAS inilah yang akhirnya menimbulkan permasalahan yang kompleks sampai tahun 2014.

Tahun Ajaran 2004/2005 SD Muhammadiyah Sapen tetap melaksanakan PATAS Pola I seperti di atas untuk seluruh siswa kelas I.Tahun Ajaran 2005/2006 SD Muhammadiyah Sapen mengevaluasi pelaksanaan PATAS untuk no. 4 dan no.5 di atas yang tidak berjalan dengan baik, karena ternyata tidak semua siswa mampu mengikuti program PATAS sehingga untuk kepentingan siswa maka Pola I disederhanakan menjadi PATAS tipe lain yaitu tipe 3 tahun menjadi 2 tahun dengan pertimbangan: (a) mencontoh pelaksanaan akselerasi Depdiknas dari tingkat SD, SMP, SMU yang menggunakan tipe 3 tahun menjadi 2 tahun, (b) sebagai antisipasi adanya UAS Da/Nas bagi siswa kelas VI kelak dan (c) Materi kelas VI sangat berat bila diPATAS-kan.

Di samping itu, kesanggupan orang tua ditambahkan poin bersedia dikembalikan ke kelas reguler apabila dalam perkembangannya tidak mampu mengikuti program PATAS sesuai dengan ketentuan untuk menjaga kualitas PATAS agar tetap 
baik. Dengan evaluasi tersebut dihasilkan Kelas PATAS: PATAS Tipe III-IV-V 3 Kelas (142 siswa) dan PATAS Tipe II-III-IV 2 Kelas (82 siswa)

Kegiatan belajar mengajar di kelas akselerasi di dukung oleh seorang kepala sekolah, guru dari beberapa guru mata pelajaran, dan 2 psikolog dari UGM. Dilihat dari guru pelaksanaan kelas akselerasi sudah memadai. Ditinjau dari latar belakang pendidikannya, sebagian besar guru di kelas akselerasi ini sudah memadai yakni tingkat sarjana dan sebagian sudah strata S-2. Setatus guru sudah merupakan guru tetap pada SD Muhammadiyah Sapen yang sudah mempunyai Nomor Induk Guru Muhammadiyah. Kondisi tingkat pendidikan dan status guru pada kelas akselerasi di SD Muhammadiyah Sapen Yogyakarta dapat dilihat pada Tabel 1.

Tabel 1. Tingkat Pendidikan dan Status Kepegawaian Guru akselerasi SD Muhammadiyah Sapen Yogyakarta

\begin{tabular}{lccc}
\hline No & $\begin{array}{c}\text { Tingkat } \\
\text { Pendidikan }\end{array}$ & \multicolumn{2}{c}{ Status Kepegawaian } \\
\cline { 3 - 4 } & & $\begin{array}{c}\text { Guru } \\
\text { Tetap }\end{array}$ & $\begin{array}{c}\text { Guru Tidak } \\
\text { Tetap }\end{array}$ \\
\hline 1 & S3 & - & - \\
2 & S2 & 2 & - \\
3 & S1 & 5 & - \\
\hline
\end{tabular}

Melihat kondisi guru dari pendidikannya tidak diragukan lagi untuk mendampingi siswa akselerasi. Kodisi pendidik sebagai guru tetap pada Muhammadiyah menjadikan kemantapan untuk melaksanakan tugas sehari hari di kelas akselerasi.

Pelaksanaan akselerasi dilakukan di kelas II, III, dan IV ditempuh selama dua tahun. Satu tahun dilaksanakan untuk tiga semester dan diampu oleh satu wali kelas. Jadi kelas III, IV, dan V hanya diperlukan dua orang wali kelas. Hal ini dilakukan untuk penghematan pengeluaran pembiayaan. Kondisi lima tahun terkhir siswa yang diterima di kelas akselerasi tersaji pada Tabel 2.
Tabel 2. Kondisi Siswa dari 2010 sd 2014 Kelas Akselerasi

\begin{tabular}{|c|c|c|c|c|}
\hline $\mathrm{N}$ & Ta. Ajaran & Pendaftar & Diterima & Keterangan \\
\hline 1 & $2009 / 2010$ & 449 anak & 23 siswa & Lulus 2011/2012 \\
\hline 2 & $2010 / 2011$ & 374 siswa & 27 siswa & Lulus 2012/2013 \\
\hline 3 & $2011 / 2012$ & 383 siswa & 25 siswa & $\begin{array}{l}\text { Kelas VI TA } \\
2013 / 2014\end{array}$ \\
\hline 4 & $2012 / 2013$ & 352 siswa & 25 siswa & $\begin{array}{l}\text { Kelas IV smt } 2 \\
\text { sd Kelas V smt } 1 \\
\text { dan } 2\end{array}$ \\
\hline 5 & $2013 / 2014$ & 430 siswa & 24 siswa & $\begin{array}{l}\text { Kelas III smt } \\
\text { 1dan } 2 \text { sd kelas } \\
\text { IV smt } 1\end{array}$ \\
\hline
\end{tabular}

Dari data tersebut dapat dikatakan bahwa jumlah pendaftar dan yang diterima sangat selektif. Jumlah siswa yang diterima tidak diharuskan seperti kelas reguler antara 28 sampai dengan 32. Jumlah yang ada ditentukan ada tidaknya tahun tersebut siswa yang masuk kategori giffted (berbakat) seperti halnya kelas reguler. Kelas ini membutuhkan seleksi yang begitu ketat terhadap calon siswa. Kesanggupan orang tua sinergi dengan kemauan anak untuk di kelas akselerasi. Kesanggupan orang tua ini dibuktikan dengan peran aktif dalam mendampingi anaknya.

\section{Implementasi Program Akselerasi}

Rekrutmen Siswa Baru Akselerasi di SD Muhammadiyah Sapen Yogyakarta

Rekrutmen siswa akselerasi dilakukan berbagai tahapan, menurut I (Kabag Litbang)

Kita sudah punya seleksi sesuai standar Dirjen. Melihat nilai rapot semester I dari kelas2 dari 5 bidang studi mendapat nilai rata-rata 85, selanjutnya siswa dapat mengikuti tahapan berikutnya. Sifatnya pilihan bukan paksaan. Pemberitahuan pada orang tua, psykotes, IQ 130 maka disarankan untuk program akselerasi ada tes lagi tes potensi akademik tes di atas standar lulus dilanjutkan wawancara. Wawancara dengan asessor. Ada tes kesehatan ada tim dokter, baru setelah melalui tahapan tahapan tersebut orang tua siap mendampingi anaknya. 
Rekrutmen menurut SZ (seksi Layanan Akselerasai) mengatakan berikut:

Untuk rekrutmen kelas akselerasi dengan melihat rata-rata hasil rapot pada semester I pada kelas 2. Rata- ratanya minimal 85 untuk lima bidang studi (Matematika, IPA, Bahasa Indonesia, PAI, dan Bahasa Inggris) setelah rata-ratanya sudah tercapai dilanjutkan dengan sosialisasi terhadap orang tua siswa. Sosialisasi selesai ada tes akademik, wawancara,dan kesehatan.

Sedangkan menurut S (Kepala Sekolah) mengatakan sebagai berikut:

Rekrutmen mulai dilaksanakan pada kelas dua semester 2 dengan melihat nilai akademik dari rapot semester I. Nilai rapot yang mencapai rata-rata 85 berhak mengikuti seleksi berikutnya. Sebelum seleksi berikutnya orang tua kita kumpulkan untuk mendapat sosialisasi tentang layanan khusus baik akselerasi maupun CI MIPA. Sosialisasi ini dilaksanakan pada hari Minggu pada pertemuan konsultasi prestasi siswa kelas dua. Tes dilanjutkan dengan tes psykologi dari Fakultas Psykologi UGM tes ini yang menentukan ke akselerasi apa CI MIPA. Hasil tes Psykologi ini siswa minimal IQ nya 130 dan bisa juga dengan IQ 125 tetapi ada komponen nilai lain yang mendukung. Ada juga yang IQ-nya 150 tidak diterima di akselerasi karena ada komponen yang lain tidak mendukung. Tes berikutnya tes akademik untuk melihat kembali kemampuan siswa dan yang terakhir tes kesehatan.

Sedangkan menurut salah satu wali siswa dari Pleret Bantul mengatakan "tes akademik, tes psikologi, kesehatan, wawancara, dan kesanggupan orang tua".

Informasi rekrutmen dari beberapa sumber dapat dirangkum sebagai berikut: (1) informasi pendaftaran siswa akselerasi, (2) tahapan seleksi calon siswa akselerasi dengan tahan tes akademik, wawan cara, tes Psikologi, tes akademik yang ke dua, kesanggupan orang tua siswa dan tes kesehatan dari tim dokter yang ditunjuk oleh SD Muhammadiyah Sapen
Upaya Peningkatan Kemampuan Guru Akselerasi di SD Muhammadiyah Sapen

Upaya peningkatan guru dari Dikpora yaitu melalui PLB yang membawahi layanan kelas akselerasi tidak ada. Hal ini sesuai dengan yang disampaikan oleh $\mathrm{S}$, seksi PLB Dikpora DIY.

Kalau yang di Sapen itu kita memberikan biasiswa dan mengikutkan lomba Sains dan matematika untuk anak akselerasi, peningkatan guru belum, kalau peningkatan kepala sekolah adanya koordinasi melalui rapat koordinasi.

Usaha yang dilakukan kepala sekolah untuk meningkatkan kemampuan guru akselerasi melalui diklat seperti yang disampaikan SZ

Mengirim diklat, ataupun mengundang nara sumber dari luar untuk pelaksanaan dilkat di SD Sapen. Diklat di luar kota biasanya kepala sekolah sendiri dan selanjutnya kepala sekolah memberikan hasil diklat kepada guru guru akselerasi.

Dari pernyataan ini, jika diklat di luar kota yang berkaitan dengan diklat akselerasi kepala sekolah sendiri yang berangkat. Guru-guru akselerasi akan mendapatkan materi diklat dari kepala sekolah.

Sedangkan usaha peningkatan guru menurut S (kepala sekolah) pada tanggal 3 Maret 2014 di kantor kepala sekolah, mengatakan:

Ya diikutkan diklat yang diselenggarakan oleh pemerintah dari tingkat kota sampai dengan nasional. Disamping itu setiap libur semester SD Sapen melaksanakan diklat mandiri. Diklat mandiri kita gunakan untuk peningkatan kemampuan guru dengan mendatangkan nara sumber atau dari nara sumber guru Sapen. Dengan mengikutkan ke diklat pembelajaran, TI dan Bahasa Inggris. Untuk TI guru aksel sudah tidak ada masalah karena sudah biasa menggunakan dalam pembelajaran. Pendidikan ke S2 ini secara umum bagi guru yang masa kerjanya mencukupi. Guru akselerasi ada pendampingan dari UKP UGM agar paham dengan anak akselerasi. 
Data upaya peningkatan guru akselerasi menurut sumber tersebut, sebagai berikut: (a) dikpora melalui seksi PLB belum ada program peningkatan guru, (b) diklat berkaitan dengan akselerasi di luar kota dilakukan oleh kepala sekolah sendiri, baru diimabaskan ke guru akselerasi, (c) pengiriman diklat pembelajaran yang diselenggarakan diluar PLB, (d) diklat mandiri yang diselenggarakan oleh SD Muhammadiyah Sapen dan (e) pendampingan psikologi dari UKP UGM

Pemanfaatan Sarana dan Prasarana Kelas Akselerasi di SD Muhammadiyah Sapen Yogyakarta

Pembelajaran di SD Muhammadiyah Sapen Yogyakarta selalu menyeimbangkan tiga ranah pendidikan yaitu, kognisi, afeksi, dan psiomotor. Guna pembelajaran afeksi terutama penanaman keislaman kepada para siswa maka SD Muhammadiyah Sapen dilengkapi dengan sebuah masjid. Masjid ini diberi nama Safinatunnajah. Masjid berkapasitas 700 orang ini selain digunakan untuk kegiatan beribadah dan pembelajaran keagamaan, juga digunakan sebagai masjid jami'. kegiatan seperti sholat Dhuha, Sholat Dhuhur berjamaah, Sholat Jumat, dan kegiatan pembiasaan beribadah selalu dilakukan di sini.

Laju perkembangan dan kemajuan teknologi komunikasi dan informasi sangat cepat. Hampir di setiap kantor, perusahaan ataupun lembaga pendidikan semuanya menggunakan komputer sebagai alat untuk menyimpan dan mengolah data. Bagi mereka yang tidak menguasai bahasa komputer maka mereka tidak akan mampu berbuat apa-apa ketika dihadapkan pada pekerjaan yang membutuhkan keahlian dalam bidang komputer.

Dalam rangka membina dan mengembangkan bakat para siswa, SD Muhammadiyah Sapen memiliki fasilitas Lab. Musik dengan peralatan lengkap baik alat musik pentatonis maupun diatonis. Beberapa keterampilan bermain musik dan berolah suara dibimbing oleh guru-guru yang kompeten. dari lab. musik inilah lahir Lambabina Band yang telah menorehkan prestasi baik di tingkat regional maupun nasional, juga orkestra sapen, dan paduan Suara

Bahasa asing merupakan dasar bagi pengembangan keilmuan. Ia merupakan kunci pembuka ilmu pengetahuan bagi anak didik. Sadar akan hal itu, maka pengajaran bahasa asing sangat ditekankan di SD Muhammadiyah Sapen Yogyakarta. Pengajaran bahasa Arab pada tahun 1994 mulai diberlakukan mulai kelas empat dan bahasa Inggris pada tahun 1985 mulai diajarkan sejak kelas satu sekolah dasar.

Perpustakaan SD Muhammadiyah Sapen Yogyakarta sangat nyaman dan lengkap sekali dalam hal buku bacaannya. buku pelajaran ataupun buku cerita tersedia disini. dengan ruangan yang nyaman, para siswa sangat menikmati membaca berbagai buku di perpustakaan ini.

UKS (Usaha Kesehatan Sekolah) merupakan tempat untuk memberikan bantuan pengobatan bagi murid ataupun karyawan yang sedang tidak enak badan, dengan dibantu tenaga yang ahli di bidangnya. UKS SD Muhammadiyah Sapen Yogyakarta ini memberikan pelayanan yang sangat membantu mereka yang membutuhkan pertolongan pertama.

Gamelan jawa yang ada untuk mempertahankan kebudayaan melalui kegiatan karawitan. Kegiatan karawitan ini sudah biasa ditampilkan untuk acara-acara di sekolah dan di luar sekolah seperti di Hotel dan kantor Dikpora DIY. Pembina karawitan didatangkan langsung dari alumni ISI Yogyakarta.

Pembelajaran di kelas akselerasi begitu cepat dan memerlukan sarana pendukung untuk pembelajaran. Komputer dan LCD yang dilengkapi dengan hotspot. Materi yang tidak lengkap dapat ditunjang dengan sarana yang ada di internet ini. Pengguanaan Internet dapat menggairahkan pembelajaran, anak-anak antusias mengikuti pembelajaran yang berlangsung. Hal ini sesuai dengan yang terjadi pada kegiatan pembelajaran IPS oleh Ibu E di kelas IV semester I. 
Upaya Kepala Sekolah Memotivasi Guru Akselerasi di SD Muhammadiyah Sapen Yogyakarta

Upaya Kepala sekolah untuk memotivasi guru adalah usaha-usaha yang dilakukan kepala sekolah untuk meningkatkan semangat kerja guru akselerasi. S mengatakan:

Ya, pastilah setiap kita ada pertemuan pasti kita sampaikan motivasi terhadap tugas yang dilakukan. Selain dari kepala, sekolah juga menggunakan dari pihak psykologi dari UKP UGM agar dapat suport (motivasi) dari orang yang tahu( kompeten) tentang anak akselerasi.

SZ mengtakan "ada tunjangan karena mereka kerja lebih berat karena 3 tahun jadi 2 tahun. Guru menyiapkan pembuatan soal, dan silabus. Jadi ada tambahan sendiri". Hal senada disampaikan oleh guru kelas IV akselerasi". Dalam bentuk penggajian. Koordinator dan guru akselerasi dapat tambahan tunjangan dalam penggajian.

Motivasi yang dilakukan kepala sekolah kepada guru akselerasi secara formal dan non-formal. Secara formal dilakukan bersama-sama pada tiap hari Rabu. ada tunjangan karena mereka kerja lebih berat karena 3 tahun jadi 2 tahun. Guru menyiapkan pembuatan soal, dan silabus. Jadi ada tambahan sendiri". Hal senada disampaikan oleh koordinator guru akselerasi mengatakan " Dalam bentuk penggajian, koordinator, guru akselerasi dapat tambahan tunjangan dalam penggajian".

Motivasi yang dilakukan kepala sekolah kepada guru akselerasi secara formal dan non-formal. Secara formal dilakukan bersama- sama pada tiap hari Rabu dan hari Minggu. Hari Rabu ada pertemuan kepala sekolah, kabag dan guru. Pertemuan ini tidak saja guru akselerasi tetapi juga guru reguler dan CI MIPA. Secara informal dilakukan dengan tanpa batas ruang dan waktu dapat bersifat rilek antara guru dengan kepala sekolah atau antara guru dengan guru.

Motivasi yang ada di SD Muhammadiyah Sapen dalm bentuk penghargaan dan finansial ada, seperti yang disampaikan Ilman, yakni: Motivasi pembelajaran, umroh gratis sesuai masa kerja, gaji 13 pada bulan Juli, gaji 14 ada saat idul fitri, Melanjutkan studi S2 sekolah memberi dana stimulan, tidak $100 \%$ untuk administrasi awal dan administrasi akhir untuk menngerjakan tesis

Motivasi dilaksanakan tiap hari Rabu, semua guru SD Muhammadiyah Sapen berkumpul untuk mendapatkan motivasi. Motivator pada hari Rabu itu kepala sekolah, dan mendatangkan narasumber dari Psikolog UGM. Pelaksanaannya setelah jam effektif selesai. Motivasi pada hari Rabu untuk meningkatkan kemampuan guru memberikan pelayanan terhadap siswa SD Muhammadiyah Sapen. Motivasi berkaitan dengan tugas dan keagamaan

Khusus untuk guru akselerasi ada motivasi dari psykologi UGM yang memahami dan kompeten dibidang anak akselerasi. Motivasi ini untuk meningkatkan pemahaman guru pemahaman guru terhadap siswa akselersilah. Permasalahan yang ada di kelas akselerasi dapat dikonsultasikan untuk mendapatkan pemecahannya.

Usaha yang telah dilakukan oleh kepala sekolah dalam memotifasi guru akselerasi yaitu: setiap ada pertemuaan kepala sekolah selalu memotivsi guru, secara finansial guru akselerasi tambahan pendapatan melalui peningkatan gaji, dan adanya motivasi dari UKP UGM. Pemberian motivasi ini untuk meningkatkan kinerja guru akselerasi supaya lebih giat lagi.

Dari data upaya kepala sekolah memotivasi guru akselerasi dapat disimpulkan, yakni: setiap ada pertemuan kepala sekolah selalu memberikan motivasi, secara finansial ada tunjangan gaji, dan pemberian motivasi dari psikolog UGM.

Pelaksanaan Supervisi pada Kelas Akselerasi di SD Muhammadiyah Sapen Yogyakarta

Kelas yang ada di SD Muhammadiyah Sapen cakupannya luas ada 76 kelas dari kelas reguler, CI MIPA dan Kelas akselerasi. Jika pelaksanaan supervisi dibebankan pada kepala sekolah tentunya tidak dapat terlaksana. Hal ini sesuai 
dengan hasil wawancara pada hari Senin 3 Maret 2014 pukul 10.00 sd 11.00 WIB tersebut $\mathrm{S}$ mengatakan:

Untuk supervisi kita tidak membedakan antara kelas akselerasi dan reguler. Setiap guru berhak mendapatkan layanan supervisi dari kepala sekolah. karena kita punya tim maka guru senior dan para wakil diberikan tugas untuk melaksanakan itu.Di SD Muhammadiyah Sapen manajemen sudah jalan jadi tidak setiap tugas kepala sekolah melaksanakan tetapi didelegasikan kepada guru yang mempunyai kompetensi.

Pelaksanaan supervisi kepala sekolah mendelegasikan kepada guru senior wakilwakilnya dan staf kabag. Pendelegasian ini sebagai tindakan manajemen yang sangat baik dari kepala sekolah karena kelas yang banyak tidak hanya kelas akselerasi. Khusus untuk kelas akselerasi menugaskan kepada koordinator, kabag pengajaran, seksi pelayanan kelas akselerasi.

Waktu pelaksanaan supervisi sudah direncanakan oleh bagian Pendidikan dan pengajaran. Supervisor dalam melakukan supervisi tidak selalu memberi tahu pada guru yang akan di supervisi. Hal ini sesuai pernyataan dalam wawancara pada tanggl 30 Januari 2014 dari wali kelas 4 sekaligus koordinator guru akselerasi yang mengatakan "Ya, biasanya mendadak ke kelas akselerasi tetapi kadang Pak Saidjan pada hari Kamis."

Dalam pelaksanaan supervisi hasilnya ada yang sudah di atas standar dan ada yang di bawah standar. Hasil temuan yang di bawah standar ditindaklanjuti dengan memberikan bimbingan kepada guru yang bersangkutan bahkan di lakukan simulasi pembelajaran sebagaimana hasil wawancara dengan I (Bagian litbang) pada hari Sabtu 1 Maret 2014 dari pukul 10.00 sd 11.00 yanag menyatakan:

"Ya. Tentu dalam supervisi ada kelebihan dan kekurangan, tindak lanjut dari kekurangan pasti ada untuk meningkatkan pelayanan siswa. Bahkan tindak lanjutnya ada simulasi pembelajaran." Begitu besarnya tekad sekolah untuk melayani siswa akselerasi, untuk memperbaiki pelayanan seorang guru yang sudah mengajar ber- tahun tahun masih perlu melakukan simulasi dihadapan guru dan supervisor. Hasil simulasi ini didiskusikan apa yang menjadi kelebihan dan kekurangannya. Kekurangan-kekurangan dicarikan solusinya untuk peningkatan pelayanan.

Di SD Muhammadiyah Sapen juga berjalan supervisi klinis oleh teman sejawat seperti yang terjadi pada pengalaman salah satu wali kelas akselerasi. Hal ini sesuai dengan hasil wawancara dengan $\mathrm{E}$ pada hari 30 Januari 2014 di ruang kelas III akselerasi yang mengatakan:

Waktu awal saya terasa berat karena sebelumnya di kelas reguler 5 tahun saya nyantai. Satu tahun pertama saya kaget tapi saya banyak bertanya pada Pak Basuki pengalaman beliu mengatakan menjadi wali kelas akselerasi, dua tahun saya tak ada masalah dalam mengelola kelas akselerasi.

Supervisi klinis pada teman sejawat yang terjadi pada Ibu Emi kepada guru yang pernah jadi wali kelas akselerasi. Wali kelas yang baru perlu memahami karakter dan perencanaan untuk kegiatan satu smester yang akan datang. Pengalaman yang dialami oleh Bapak Basuki ingin di tiru apa yang baik bagi bagi kelas akselerasi.

Kendala dalam Implementasi Program Akselerasi di SD Muhammadiyah Sapen Yogyakarta

Kendala dalam setiap program apapun pasti ada. Kendala kendala tersebut dapat teratasi apabila dikomunikasikan. Kendala yang ada dalam implementasi kurikulum:

Berkaitan orang tua tentang pendampingan anaknya dari SP (wali siswa) mengatakan "Untuk mendampingi anak saya biasa saja saya enjoy senang tidak ada masalah. Saya kasihan jika anak yang mempunyai kecerdasan lebih, masuk di kelas reguler".

Sedangkan menurut GW (wali siswa) mengatakan:

Dalam pendampingan anak, saya berbagi dengan istri yang lebih istri, saya $25 \%$ istri saya $75 \%$. Pendampingan tidak menjadikan masalah karena sudah di bagi 
dengan istri, tapi jika saya tugas di luar $R S$ Sarjito atau mengajar di UGM dan istri sibuk dengan menggambar, pendampingan jadi tidak maksimal"

Dari pendapat ini ada pembagian tugas antara ibu dan bapak dengan porsi $25 \%$ dan $75 \%$. Pendampingan jadi tidak maksimal jika ada kesibukan karena tugas bekerja ataupun pekerjaan ibu si anak. Sedangkan pernyataan SM (wali siswa)

" berkaitan dengan pendampingan anak, saya yang mendampingi di rumah, saya tidak masalah enjoy- enjoy saja. Kakaknya dulu dari Sapen juga ikut di aksel jadi sudah dua kali ini saya mendampingi, tidak ada masalah". Orang tua ini tidak ada masalah dalam pendampingan karena sudah berpengalaman mendampingi kakaknya yang masuk kelas akselerasi.

Sedangkan pernyataan R.V. (wali siswa) mengatakan:

Nggak sih, cuman anaknya bosan ulangan terus. Tidak ada masalah dalam pendampingan, aksel tidak jaminan anaknya pintar, ada yang matematika ulangan dapat 4. Pandangan orang kelas aksel anak-anak pintar ternyata yang kurang juga ada.

Dilihat dari pendampingan orang tua tidak ada masalah. Anak sebagi subjek didik merasa bosan belajar terus untuk menghadapi ulangan.

Pendapat $Y$ salah satu wali siswa akselerasi berkaitan dengan pendampingan, mengatakan:

Rumah ini dari halaman sampai dalam rumah penuh dengan barang kerajian, tak ada tempat khusus untuk belajar, bapak saja duduk di bawah seperti ini. Saya ini bekerja dari pagi sampai malam, saya juga menunggui anakku belajar, tetapi yang terjadi saya yang tertidur di sampingnya.

Pendampingan yang dilakukan $\mathrm{Y}$ selaku orang tua mengalami kesulitan karena adanya pekerjaan yang padat. Ibu ini bekerja membuat kerajinan untuk di eksport ke Eropa. Wali siswa ini mengasuh anaknya sendiri di rumah sedangkan suaminya bekerja di Jakarta. Sehingga pendampingan anaknya tidak maksimal. Pendampingan anak aksel sangat berbeda dengan kelas reguler. Perbedaan pendampingan ini karena waktu yang beda sedangkan materi dipadatkan. Pendampingan yang seorang diri dan pekerjaan yang padat dari pagi sampai sore orang tua sudah kelelahan.

Pernyataan wali siswa dari AR tentang pendampingan cucunya, mengatakan:

Ya, mestinya beda waktu kelas 1 dan 2 kan tidak begitu ketat sekarang lebih ketat. Kalau anak usia segitu senang-senangnya main. Main boleh sampai setengah 17.30 mereka kalau belajar terlalu lama bosan. Belajar pukul 19.00 sd 20.00. Pukul 04.00 sudah bangun mandi belajar makan berangkat sekolah. anaknya sudah mandiri jadi pendampingannya tidak merepotkan orang tua.

Pendapat wali siswa ini dalam pendampingan cucunya tidak ada masalah anak sudah mempunyai tanggung jawab dan dan kemandirian sebagai siswa akselerasi. Kemandirian siswa ini ditunjukkan dalam membagi waktu untuk belajar di rumah. Lebih lanjut $Y$ mengatakan:

$Y a$ itu yang menjadi kelemahan saya. Saya dari pagi bekerja, anak jika les dari pagi sampi sore, Jeda waktu pukul 4, 5 sampai magrib, magrib isak belajar. Saya dari isak sampai pukul 21.00 sudah lelah, sementara besok pagi anak ulangan. Dua minggu itu terasa cepat. Sekarang terima rapot, seminggu berikutnya belajar, seminggu lagi ulangan harian, seminggu berikutnya belajar, minggu berikutnya mid semester, dilihat dari bahannya ya begitu saja tapi anak mengalami kebosanan, bosan karena belajar.

Pernyataan $\mathrm{Y}$ anak mengalami kebosanan dalam belajar. Jadwal yang padat yang berisi jadwal kegiatan belajar siswa dalam satu semester. Waktu terasa cepat karena beban belajar dari anak.

Dari pendapat beberpa pendapat wali siswa dapat di simpulkan ada dua kendala dalam implemementasi kurikulum akselerasi yaitu: (a) sebagian orang kesulitan dalam mendampingi anaknya dan (b) anak mengalami kebosanan dalam belajar. 
Pembahasan

Rekrutmen Siswa Baru Akselerasi di SD Muhammadiyah Sapen Yogyakarta

Siswa dan kurikulum bagaikan dua mata sisi uang yang tidak dapt dipisahkan. Siswa akselerasi dan pelaksanaan kurikulum harus sepadan (imbang) Kasalahan dalam rekrutmen siswa akselerasi dapat berakibat pada tidak berhasilnya pelaksanaan kurikulum akselerasi. Maka dari itu perekrutan siswa baru akselerasi harus prosedur menurut aturan yang sudah ditentukan SD Muhammadiyah Sapen Yogyakarta. Tujuannya dari rekkrutmen ini untuk mendapatkan siswa yang sesuai dengan PP No.17 tahun 2010 tentang Pengelolan dan penyelenggaraan pendidikan.

Menurut Msnks \& Pfuger (Herman \& Bruch 2011, p.50) mengatakan atas permintaan orang tua, anak bisa masuk sekolah lebih awal, meskipun keputusan biasanya sampai dengan administrasi sekolah, kadang-kadang di bawah pertimbangan pendapat ahli. Sejak saat itu, nilai yang sangat baik merupakan prasyarat bagi partisipasi dalam sebagian besar program dan kegiatan di sekolah. Pengecualian adalah kompetisi dalam sekolah yang sering terbuka untuk setiap siswa yang ingin berpartisipasi, tetapi nilai jarang satu-satunya kriteria. Keputusan untuk memungkinkan siswa untuk berbagi kelas dengan nilai yang lebih tinggi atau melewatkan kelas, misalnya, biasanya didasarkan pada nilai tinggi, motivasi apapun, dan nominasi guru/rekomendasi. Hasil pemeriksaan melalui psikolog sekolah juga dapat dimasukkan dalam proses.

Berdasarkan landasan yang ada dan pelaksanaan rekrutmen siswa akselerasi di SD Muhammadiyah Sapen. Pelaksanaan rekrutmen di SD Muhammadiyah dilaksanakan berdasarkan prosedur yang ditentukan secara berurutan. Rekrutmen tersebut dapat dipertanggung jawabkan. Dari sisi akreditasi sekolah sudah memenuhi syarat untuk pelaksanaan program akselerasi yaitu akreditasi A.
Upaya Peningkatan Kemampuan Guru Akselerasi di SD Muhammadiyah Sapen Yogyakarta

Upaya yang dilakukan untuk meningkatkan kemampuan guru melalui diklat pembelajaran, TI, dan Bahasa Inggris. Materi ini secara umum bersama dengan guru reguler dan CI MIPA. Pelaksanaan ini belum menyentuh pembelajaran yang sepadan dengan karakteristik anak akselerasi. Upaya peningkatan secara khusus untuk guru akselerasi yaitu Pendampingan oleh psykolog dari UKP UGM Yogyakarta dan diklat dari kepala sekolah dengan materi dari hasil diklat yang diselenggarakan pengurus CI-BI (cerdas istimewa-berbakat istimewa).

Penelitan penyiapan guru ini Geake and Gross (Plunkett \& Kronborg 2011, p.33) mengatakan para guru yang telah menyelesaikan apa yang mereka ikuti sebagai sebuah program pengembangan profesional berkelanjutan berbakat di bidang pendidikan di Australia, Inggris dan Skotlandi, bahwa guru secara signifikan lebih positif terhadap siswa berbakat daripada rekan-rekan mereka yang belum selesai mengikuti program pengembangan profesional berkelanjutan .

Di SD muhammadiyah Sapen sudah meningkatkan kemampuan guru secara mandiri bergabung dengan Assosiasi CI-BI dan mengikuti diklat dari CI-BI. Peningkatan pemahaman guru terhadap siswa akselerasi dengan adanya pendampingan dari UKP UGM. PLB (Pendidikan Luar Biasa) yang membawahi layanan khusus akselerasi belum punya program untuk peningkatan guru akselerasi.

Pemanfaatan Sarana dan Prasarana Kelas Akselerasi di SD Muhammadiyah Sapen Yogyakarta

Sarana pendidikan merupakan sarana bagi proses belajar mengajar. Sarana penunjang yang ada saat ini. Pengadaan dan perawatan sarana dan prasarana di lakukan oleh sekolah. Peran orang tua dalam pengadaan melalui pendanaan pada daftar ulang. Sarana yang ada tidak dilihat dari lengkap dan tidaknya tetapi dari kemanfaatannya. Sarana yang ada dapat digunakan secara effektif dan efisien. 
Berkaitan dengan effektif dan efisien sarana Daryanto \& Farid (2009, p.123) mengatakan:

Ada dua prinsip yang harus diperhatikan dalam pemakaian perlengkapan pendidikan yaitu prinsip efektivitas dan prinsip efisiensi. Prinsip efektifitas berarti semua pemakaian perlengkapan pendidikan di sekolah harus ditunjukkan semata-mata dalam rangka memperlancar pencapaian tujuan pendidikan sekolah baik secara langsung maupun tidak langsung. Sedangkan prinsip efisiensi berarti pemakaian semua perlengkapan pendidikan di sekolah secara hemat dan dengan hati-hati.

Penerapan dua prinsip di atas SD Muhammadiyah telah menyiapkan sumber daya manusianya. Pada pembelajaran komputer telah menempatkan guru komputer yang kompeten sehingga secara efektif dan efisiean dapat menggunakan. Jika terjadi kerusakkan sudah dapat memperbaiki sendiri.

Guru komputer yang ada saat ini yaitu TR alumni SI komputer dari STIMK. Jika ada kerusakan guru tersebut dapat memperbaikinya sehingga dapat menghemat pngeluaran. Pengajar komputer yang kompeten pada bidangnya menjadikan efektif dan efisien pembelajaran di kelas akselerasi SD Muhammadiyah Sapen.

Kegiatan karawitan ditangani oleh guru dari alumni ISI yang mumpuni pada penguasaan materi dan perawatan alatnya. Kerusakaan dari alat dapat ditangani segera karena kepekaan terhadap seni yang dimiliki guru. Keselarasan bunyi gamelan senantiasa terkontrol.

Berdasarkan observasi pada penggunaan sarana yang ada peneliti mengamati penggunaan LCD pada kelas IV akselerasi anak-anak pada saaat pembelajaran tentang candi borobudur dan prambanan sangat antusias sekali. Guru sudah terbiasa menggunakan sarana internet untuk belajar. Penggunaan internet ini juga dapat dilakukan oleh siswa secara berkelompok baik di kelas maupun di lab. komputer.
Upaya Kepala Sekolah Memotivasi Guru Akselerasi di SD Muhammadiyah Sapen Yogyakarta

Seorang manajer yang memahami peran dari motivasi, menempatkan motivasi sebagai unsur utama dalam pendekatan kepada anak buah. Pendelegasian wewenang, pengendalian, dan pengarahan anak buah perlu disertai motivasi (Sulistyiani \& Rosidah 2009, p. 233)

Pendelegasian guru untuk mengajar pada kelas akselerasi diikuti dengan pemberian motivasi dari kepala sekolah. Pemberian motivasi ini agar guru mempunyai kesanggupn mengajar pada kelas akselerasi. Jika kegiatan pemberian motivasi guru tidak optimal maka guru akan berusaha untuk tidak mengajar pada kelas akselerasi.

Kehidupaan manusia dihadapkan dengan berbagai kebutuhaan dari yang dasar sampai tingkatan tinggi. Kebutuhn manusia ini akan menjadi rangsangan dari pimpinan untuk memberikan motivasi. Motivasi dilaksanakan secara formal melalui pertemuan yang diagendakan oleh sekolah.

Motivasi formal di SD Muhammadiyah Sapen dilaksanakan pada hari Rabu dan hari Sabtu karena hari Rabu dan Sabtu itu untuk peningkatan dan diskusi antara guru di SD Sapen. Motivasi formal dalam bentuk finansial hal ini sesuai dengan tingkatan dasar. Fisiologis kebutuhan: lapar, haus, seksualitas, dan sebagainya, dan kebutuhan tempat tinggal. Kebutuhan ini kebutuhan yang paling dasar jika guru akselerasi dicukupkan keuangaannya berarti sekolah tersebut dapat melaksanaakan motivasi baik dasar sampai aktualisasi diri. Bentuk motivasi ini melalui peningkatan gaji yang lebih dari guru reguler dan $\mathrm{CI}$ MIPA.

Motivasi informal dilaksanakan secara fleksible tanpa dalam rapat tetapi dalam situasi tidak resmi. Pemberian motivasi ini cocok dalam face to face yang berbentuk pujian untuk mengakui keberadaan guru akselerasi.

Melalui pengajian pada hari Minggu yang dihadiri oleh guru secara bergantian 
(terjadwal) dari kelas 1 sampai dengan VI. Setelah kegiatan bersama dilanjutkan wali kelas dan wali siswa akselerasi berkumpul di kelas untuk diskusi kemajuan prestasi siswa. Wali siswa pada kegiatan ini melakukan motivasi pada wali siswa akselerasi.

Secara keseluruhan motivasi yang diupayakan oleh kepala sekolah sudah berjalan. Pemberian motivasi secara finansial berupa gaji pada kelas akselerasi seharusnya tertulis jelas tunjangannya berapa persen dari gaji pokok, misalkan $25 \%$ dari gaji pokok. Hal ini sangat penting untuk meningkatkan motivasi instrinsik dari guru akselerasi yang kelelahan dengan kecepatan waktu yang ada dari 12 bulan dalam tahun ajaran menjadi 8 bulan.

Pelaksanaan Supervisi Akademik pada Kelas Akselerasi di SD Muhammadiyah Sapen Yogyakarta

Fungsi supervisi adalah memajukan dan mengembangkan pengajaran sehingga proses belajar mengajar yang dilakukan oleh seorang guru berlangsung dengan baik dan efektif. Pembimbingan cenderung pada sikap dari supervisor yang demokratis tidak bersifat otoriter. Kemudian dalam arti atasan disamping arti hirarki juga berati kewenangan (Daryanto \& Farid, 2013, pp.179 -180)

Kewenangan melakukan supervisi sesuai hirarki pada program akselerasii di SD Muhammadiyah sapen adalah: Seksi Pelayanan program akselerasi, Kabag pengajaran dan kepala sekolah. Seksi pelayanan program akselerasi diambilkan dari guru yang berpengalaman menjadi wali kelas akselerasi. Seksi ini bertanggungjawab kepada kabag pengajaran dan kepala sekola

Hasil supervisi perlu ditindaklanjuti agar memberikan dampak nyata bagi profesionalisme guru. Tindak lanjut bagi guru yang memenuhi standar dengan penguatan dan penghargaan. Teguran yang mendidik diberikan kepada guru yang belum memenuhi standar, dan diberi kesempatan pelatihan/penataran (Prasojo \& Sudiyono, 2011, p.120)
Dalam melakukan kegiatan tindak lanjut bagi guru yang belum mencapai standar hendaknya supervisor menerapkan tugas dan fungsi supervisor kepada guru yang meliputi: koordinator, konsultan, pemimpin, dan evaluator. Hal ini sesuai dengan pendapat (Daryanto \& Farid, 2013, p.183) Tugas dan Fungsi supervisor meliputi: (1) koordinator, sebagai koordinator supervisor dapat mengkoordinasikan program belajar mengajar, (2) konsultan, sebagai sempat bertanya bagi guru untuk mengetahui cara-cara memecahkan masalah, (3) pemimpin kelompok, supervisor dapat memimpin sejumlah guru dalam mengembangkan potensi kelompok dan (4) evaluator, supervisor dapat membantu guru menilai hasil, proses belajar dan kurikulum yang sedang dikembangkan.

Tindak lanjut pada kegiatan supervisi akademik dilakukan dengan mendiskusikan kekurangan yang ada untuk diperbaiki. Ada tindak lanjut yang dilakukan dengan simulasi berupa praktek mengajar.

Kendala dalam Implementasi Kurikulum Akselerasi di SD Muhammadiyah Sapen Yogyakarta

Kendala yang ada pada implementasi kurikulum akselerasi di SD Muhammadiyah Sapen yaitu: (a) sebagian orang tua kesulitan dalam mendampingi anaknya, b) kesuliatan dalam pendampingan orang tua ini di sebabkan karena faktor lingkungan terdekat yaitu keluarga. Hal ini sesuai dengan pendapat Munandar (2007, p. 231) meliputi kurang adanya kerja sama dan saling percaya antara anggota keluarga atau antara sejawat, orang tua otokrat dan tidak terbuka terhadap ide-ide anak, ketidaknyamanan dalam keluarga, gangguan lingkungan, keributan, kegelisahan dan kurang adanya dukungan untuk mewujudkan gagasan-gagasan.

Kerja sama orang tua dalam pendampingan belajar perlu di rencanakan dengan matang. Perencanaan ini dapat secara tetap dan melihat kesibukan orang tua siswa. Jika kesibukan orang tua menjadi penyebab kesulitan pendampingan dapat mendatangkan guru untuk mendampingi belajar 
Anak akselerasi mempunyai ide-ide yang perlu mendapatkan respon baik dengan tanggapan lesan maupun tindakan menfasilitasi ide tersebut. Anak yang mempunyai ide pada seni lukis dapat difasilitasi dengan alat melukis dan lomba- lomba.

Tuntutan orang tua dalam bentuk nilai angka menjadikan anak tidak nyaman dengan orang tua. Anak merasa kurang diperhatikan dalam prosesnya. Proses perolehan nilai ini yang lebih utama. Hasil yang kurang maksimal orang tua dapat melihat bagian mana yang belum dikuasai siswa.

Gangguan lingkungan dapat tercipta oleh orang tua karena usaha yang dijalani, contohnya dalam lingkungan rumah tersebut penuh dengan barang kerajinan yang ada dari halaman sampai dapur penuh dengan hasil kerajinan. Keributan orang tua dan anggota keluarga dapat mengganggu ketenangan anak dalam belajarnya baik di rumah maupun di sekolah. Keributan keributan dapat menimbulkan kegelisahan pada diri anak. Kegelisahan ini berakibat pada menurunnya prestasi anak akselerasi. Anak yang prestasinya menurun Di SD Muhammadiyah Sapen di fasilitasi dengan pendampingan dari psikologi UKP UGM. Pendampingan ini untuk mengetahui sebab sebab anak menurun prestasinya.

Siswa yang berbakat tidak lepas dari pendidikan orang tua siswa. Artinya anak anak berbakat akan tumbuh dan berkembang dengan keluarga (orang tua) yang berpendidikan tinggi. Orang tua dengan pendidikan tinggi akan dapat menyalurkan dan memfasilitasi gagasan- gagasan yang dimiliki anak.

Kendala dari orang tua siswa dalam pelaksanaan kurikulum akselerasai merupakan kendala bagi sebagian orang tua siswa akselerasi. Kendala ini dapat diminimalkan dengan kegiatan komunikasi. Kegiatan komunikasi ini antara orang tua dengan wali kelas. Kegiatan ini di SD Muhammadiyah Sapen dinamakan konsultasi prestasi siswa. Konsultasi siswa dapat dilanjutkan ke bagian Psikologi di SD Muhammadiyah Sapen yaitu dari UKP UGM.
Anak mengalami kebosanan dalam belajar. Jadwal yang padat di kelas akselerasi SD Muhammadiyah Sapen Yogyakarta yang meliputi muatan dari pemerintah dan keagamaan membuat anak merasakan bosan akibat beban belajar dan ulangan yang terasa terus menerus menjadikan anak mengalami kebosanan juga. Kebosanan karena beban belajar dan ulangan dapat di atasi dengan meningkatkan motivasi instrinsik. Bagi siswa berbakat pembelajaran harus menantang, bahan ajar lebih majemuk dan merangsang, pemberian bacaan yang lebih maju, mempertimbangkan minat khusus, dan pendekatan fleksible dalam kegiatan belajar mengajar.

\section{Simpulan dan Saran}

Simpulan

Berdasarkan pemaparan hasil penelitian dan pembahasan dapat disimpulkan bahwa implementsi program akselerasi meliputi beberapa aspek sebagai berikut. Pertama, rekrutmen siswa baru akselerasi melalui dua tahapan yaitu informasi dan seleksi calon siswa yang meliputi: (1) tes akademik 1 dengan nilai rapot semester I kelas 2; (2) wawancara; (3) tes psikologi, (4) tes akademik yang ke 2; (5) tes kesehatan, dan kesanggupan orang tua.

Kedua adalah peningkatan kemampuan guru akselerasi melalui diklat dan pendampingan dari UKP UGM. Diklat dan pendampingan yang dilakukan untuk meningkatkan kemampuan guru. Ketiga, pemanfaatan sarana dan prasarana kelas akselerasi. Pemanfaatan sarana dan prasarana didukung oleh sumberdaya manusia yang sesuai dengan ahlinya. Ketepatan sumberdaya manusia ini akan efektif dan efisien dalam pemanfaatan sarana yang ada.

Keempat pemotivasian guru akselerasi dilaksanakan setiap ada pertemuan kepala sekolah memberikan motivasi, secara finansial guru aksel mendapat tunjangan gaji, dan pemberian motivasi dari UKP UGM. Kelima, pelaksanaan supervisi akademik pada kelas akselerasi dilakukan oleh kepala sekolah dan kabag layanan 
khusus akselerasi. Kegiatan supervisi dengan observasi ke dalam kelas melihat pelaksanaan pembelajaran. Hasil dari supervisi ditindak lanjuti bahkan ada yang ditindaklanjuti dengan simulasi pembelajaran.

Kendala dalam implementasi program akselerasi yaitu: (a) sebagian orang tua siswa akselerasi tidak maksimal dalam pendampingan anaknya; dan (b) siswa mengalami kebosanan belajar akibat beban belajar dan ulangan.

Saran

Berdasarkan kesimpulan penelitian, ada beberapa saran yang dapat disampaikan yaitu: (1) koordinasi dan komunikasi sekolah dengan wali siswa ditingkatkan, (2) peningkatan pemahaman guru pada anak akselerasi, (3) wali murid hendaknya menciptakan lingkungan rumah yang kondusif dan 4) peran PLB untuk peningkatan kompetensi guru akselerasi harap diprogramkan.

\section{Daftar Pustaka}

Creswell, J.W. (2010). Research design Qualitative, Quantitative, and, Mixed methods approaches. Edisi 3 cetakan 1, (terjemahan Ahmad Fawaid). California: Sage Publication. (Buku asli diterbitkan tahun 2009)

Daryanto \& Farid, M. (2013). Konsep dasar manajemen pendidikan di Sekolah. Yogyakarta: Penerbit Gava Media.

Herman, A \& Bruch, N. (1 Agutus 2011). Giffted education in Germanspeaking countries. Artikel diakses pada tanggal 1 Januari 2014, dari www.wordgiffted.org/sites/default/files/GTI \%2026(1\&2)\%202011volume26 number I
Hidayat, R.A. (2010). Perilaku siswa kelas akselerasi di sekolah dasar Negeri 16 Surakarta. Tesis Magister, tidak diterbitkan, Universitas Negeri Yogyakarta, Yogyakarta.

Munandar, U. (2002). Kreativitas dan keberbakatan strategi mewujudkan potensi kreativ dan bakat. Jakarta: PT Gramedia.

Plunkett, M. \& Kronborg, L. (1 Agustus 2011). Learning to be a teacher off gifted: the importance of examining opinions and challenging misconceptions. Artikel. Diambil pada tanggal 1 Januari 2014, dari www. Wordgifted.org/sites/defaul/files/GTI\%

Prasojo, L. D \& Sudiyono. (2011). Supervisi pendidikan. Yogyakarta: Gava Media

Sugiyono. (2012). Metode penelitian kuantitatif, kualitatif dan $r \mathcal{E} d$. Bandung: CV Alvabet.

Supriyanto, E. (2012). Pengembangan kurikulum pendidikan cerdas istimewa. Yogyakarta: Pustaka Pelajar.

Sudjana. (2004). Manajemen program pendidikan. Bandung: Falah Production.

Sulistyiani, A.T \& Rosidah. (2009). Manajemen sumber daya manusia. Yogyakarta: Graha Ilmu.

Tirtonegoro, S. (1984). Anak supernormal dan program pendidikannya. Jakarta: Bina Aksara 2026 (1\&2) \% 202011 volume 26 namber I

Yusuf, S. (2007). Ilmu dan aplikasi pendidikan, pendidikan anak berbakat. (Ilmu dan aplikasi pendidikan bagian II ilmu pendidikan praktis, TPIP FIP-UPI). Bandung: PT.Imperial Bhakti Utama. 